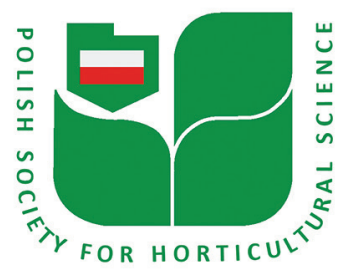

Folia Hort. 33(2) (2021): 309-324

\title{
Evaluation of the growth, drought tolerance and biochemical compositions of introduced red currant cultivars and Russian breeding genotypes in temperate continental climate
}

\author{
Olga Panfilova ${ }^{1, *}$, Volkan Okatan ${ }^{2}$, Mikhail Tsoy ${ }^{1}$, Olga Golyaeva ${ }^{1}$, \\ Sergey Knyazev ${ }^{1}$ İbrahim Kahramanoğlu ${ }^{3}$
}

\begin{abstract}
${ }^{1}$ Russian Research Institute of Fruit Crop Breeding (VNIISPK), Zhilina, Orel District, Orel Region, Russian Federation ${ }^{2}$ Department of Horticulture, Faculty of Agriculture, Eskisehir Osmangazi University, Eskişehir, Turkey ${ }^{3}$ Department of Horticulture, European University of Lefke, Gemikonagi, Northern Cyprus, via Mersin 10, Turkey
\end{abstract}

\begin{abstract}
The aim of the work was to study the growth, drought tolerance and biochemical characteristics of introduced cultivars ('Jonkheer van Tets', 'Hollandische Rote' and 'Viksne') and some selected Russian cultivars and red currant genotypes ('Shchedraya', 'Natali', 129-21-61, 111-19-81, 261-65-19 and 271-58-24). The studies were conducted between 2014 and 2018 under temperate continental climate conditions. The intensity of transpiration was determined by using a torsion balance. The soluble solid concentration (SSS - \% Brix) of the fruits was determined by using a digital refractomer. The content of the sum of sugars was determined by the weight method according to Bertrand's method. Ascorbic acid content was then determined by the iodometric method. The total phenolic content was determined by a colourimetric method. Climatic conditions were found to have significant influence on the disease severity of the red currant genotypes, while the infections caused by Sphaerotheca mors-uvae increased in optimum seasons and damages caused by Pseudopeziza ribis increased in drought seasons. None of the selected genotypes was found to be resistant to any of the diseases/pests, but 'Jonkheer van Tets', 'Hollandische Rote' and 111-19-81 were less affected by these diseases/pests. Weight, yield and raceme length of berries and the number of berries in a raceme were found to be higher in optimum seasons, and different cultivars/genotypes had superior characteristics for different parameters. The highest berry weight was observed in the 261-65-19 genotype (0.65 g), while the highest yield was noted in 'Hollandische Rote' $\left(15.6 \mathrm{t} \cdot \mathrm{ha}^{-1}\right)$. It was also found that the water content of leaves and transpiration have a strong positive relationship with soil moisture at a depth of $0-200 \mathrm{~mm}$ but a week correlation with soil moisture at a depth of 200-400 mm. Results also showed that the transpiration of leaves decreases in later developmental stages (July). Hierarchical clustering suggested four clusters: the introduced cultivars produced one cluster, Russian cultivars are another cluster, 261-65-19, 111-19-81 and 129-21-61 genotypes make up a third cluster and the 271-58-24 genotype (superior in terms of phenolic contents) forms the fourth cluster.
\end{abstract}

Keywords: adaptation, biological characteristics, disease tolerance, genotypic variability, hierarchical clustering, leaf water contents

\section{INTRODUCTION}

Berries, with their high antioxidant capacities, are among the healthiest fruits for human beings.
Moreover, they have a unique flavour, colour and diverse content of vitamins and minerals

*Corresponding author.

e-mail: us@vniispk.ru (Olga Panfilova). 
(Pereira et al., 2018; Gündeşli et al., 2019; Okatan, 2020). Commercially important berries are strawberries, blueberries, blackberries, raspberries, red currants and blackcurrants. Berry fruits can be consumed fresh or processed in the form of jams, cakes or pies. Red currant (Ribes rubrum L.) belongs to the gooseberry (Grossulariaceae) family and is reported to be native to Western Europe. However, it is now widely distributed mostly in the temperate regions of the world (Albuquerque et al., 2018). Regular consumption of the red currant fruits has been reported to have a positive influence on the prevention and/or reduction of several chronic diseases, including diabetes, some type of cancers and cardiovascular diseases (Zdunić et al., 2016). Currently, because of the scientifically confirmed nutritional values and health benefits, consumers have a special attention on the berries, which provides an opportunity for farmers to increase their berry production (Jimenez-Garcia et al., 2018). Berries have an important contribution on the development of the domestic economy of countries too (Lakomiak and Zhichkin, 2020). Most of the cultivated berries have been known to be developed by the European breeding programmes. Moreover, introduction of these cultivars into different growing (climate and soil) conditions may result in adaptation problems, low yield or changes in biochemical compositions. Since cultivar introduction is an important decision for the economy of the countries and/or regions, most of the world's research institutes include cultivar and genotype evaluation in their research programmes (Gilbert and Gardner, 2003).

The red currant market is mostly dominated by European originated cultivars including 'Jonkheer van Tets', 'Hollandische Rote' ('Prins Albert'), 'Viksne', 'Rosetta', 'Rovada', 'Rolan' and 'London Market', some old Russian cultivars like 'Natali' and 'Shchedraya' and few American cultivars, i.e. 'Red Lake'. Besides the climatic adaptation of cultivars, resistance to gooseberry mildew (Sphaerotheca mors-uvae (Schw.) Berk et Curt.) and leaf spots (Pseudopeziza ribis Kleb.) is also important. In terms of both climatic adaptability and resistance to pests and diseases, 'Augustus', 'Rolan', 'Red Pool' and 'Roodneus' cultivars are commonly grown in Denmark (Pedersen, 2007; Pedersen and Andersen, 2012), 'Detvan', 'Red Lake' and 'Primus' are commercially grown in Slovakia (Milošević and Milošević, 2018), 'White Crape', 'Blanka', 'Versailles Blanche', 'Rovada', 'Rondom', 'Junifer', 'White Pearl' and 'Jonkheer van Tets' are grown in Germany, Holland and Belgium (Hummer and Dale, 2010; Wiethold, 2016), 'Red Lake', 'Detvan', 'Rovada', 'Tatran' and 'Jonkheer van Tets' are grown in the United States of America (Bratsch and Williams, 2009), 'Jonkheer van Tets' and 'Viksne' are grown in Ukraine (Tereshchenko, 2018) and 'Jonkheer van Tets', 'Natali', 'Viksne' and 'Hollandische Rote' are grown in the Russian Federation (Rodyukova, 2008).
Production of crops in a range of environmental conditions is as important as high yield for ensuring food security on the earth. Therefore, the adaptation of different cultivars/genotypes into different environmental conditions is very important for food security. However, global climate change with extreme precipitation events, increase in temperature and drought in some places has been significantly impacting the plants' adaptation and growth in different environments (Myhre et al., 2019; Kusmec et al., 2021). Changes in $\mathrm{CO}_{2}$ concentration, precipitation and temperature also affect the growth, survival and spread of pathogens and indirectly impact crop cultivation (Zavala et al., 2008; Heeb et al., 2019). Thus, production of non-adapted cultivars in such conditions makes it difficult to obtain a high yield and requires more input. Thus, excessive use and misuse of the inputs may cause environmental degradation and induce global climate change. The plant response to climate change and to stresses is complex and includes changes at both the biochemical and physiological levels (Kumar et al., 2019; Kapoor et al., 2020). It is necessary to consider cultivar-specific physiological and biochemical reactions of plants that directly participate in the formation of adaptation processes in a particular climatic zone for a better identification of resistance in berry crops during breeding. Quite often, the consequences of drought can be seen visually as withering of leaves, reduced plant growth, shedding of the ovary and berries and decline in yield (Kawecki et al., 2006; Grabowski et al., 2009; Olen et al., 2016). Therefore, in breeding programmes, nowadays, breeders aim at adapting crops to multiple factors and climate change (Ceccarelli and Grando, 2020). On the one hand, breeders include abiotic stresses, especially drought and high temperature, and biotic stresses (the pathogens) together for them to characterise and analyse their multiple objectives. The available literature demonstrates that mainly single elements of adaptation have been studied on berry crops such as black currant, raspberry and strawberry, and data were found on some cultivars of red currant (Golyaeva and et al., 2020; Panfilova et al., 2021). According to Bratsch and Tech (2009), currant is a very sensitive crop to drought. In some black currant cultivars, the effects of drought led to a decrease in dry matter, water content, water loss and transpiration (Cosmulescu et al., 2008; Čereković et al., 2013; Netzer et al., 2019). The relationship between water exchange and drought stress was also noted for several other berry crops (Klamkowski and Treder, 2008; Morales et al., 2013; Álvarez-Herrera et al., 2019). This is mostly accepted as the initial response of adaptation mechanisms to drought stress (Chartzoulakis et al., 2002; Guerfel et al., 2009). In the present study, the growth, drought tolerance and biochemical characteristics of some introduced cultivars ('Jonkheer van Tets', 'Hollandische Rote' and 'Viksne') and some selected Russian cultivars and genotypes ('Shchedraya', 
'Natali', 129-21-61, 111-19-81, 261-65-19 and 271-58-24) were evaluated to provide complete information about cultivar resistance in the growing zone to farmers.

\section{MATERIALS AND METHODS}

\section{Experimental plot}

The present study was conducted on a loamy haplic Luvisol soil located in the zone of temperate continental climate between May and July from 2013 to 2018 in the Central Chernozem area of Russia. Characteristics of the soil were analysed separately at a depth of 0-200 $\mathrm{mm}$ and $200-400 \mathrm{~mm}$ according to the standard methods (Mineev, 2001). The thickness of the humus horizon was $300-550 \mathrm{~mm}$. In the horizon with a thickness of $0-200 \mathrm{~mm}$, the soil organic matter (OM) was $2.14 \% \pm 0.08 \%$, soil $\mathrm{pH}$ was $5.40 \pm 0.15$ and available elemental concentrations of potassium and phosphorus were $182.50 \pm 62.75 \mathrm{mg} \cdot \mathrm{kg}^{-1}$ and $208.74 \pm 27.6 \mathrm{mg} \cdot \mathrm{kg}^{-1}$, respectively. Furthermore, in the soil horizon with a thickness of $200-400 \mathrm{~mm}$, the soil OM was $1.85 \% \pm 0.06 \%$, soil $\mathrm{pH}$ was $5.5 \pm 0.2$ and available elemental concentrations of potassium and phosphorus were $125.42 \pm 38.65 \mathrm{mg} \cdot \mathrm{kg}^{-1}$ and $149.12 \pm 24.34 \mathrm{mg} \cdot \mathrm{kg}^{-1}$, respectively. The climatic characteristics of the study site during the experimental research are given in Table 1.

Besides the above given climatic data, the water availability of the region was also calculated according to the formula of Chirkov (1986) to find out optimal and drought seasons. The water availability was estimated as the value of the hydrothermal coefficient (K).

$$
K=\frac{R \times 10}{\Sigma t}
$$

In the above formula, $\mathrm{R}$ represents the amount of precipitation in millimetres and $\Sigma \mathrm{t}$ is the sum of temperatures above $+10^{\circ} \mathrm{C}$ for the same period. A lower $\mathrm{K}$ value means drier area. The hydrothermal coefficient $(\mathrm{K})$ of the experimental site during the study period is given in Table 2. According to the results obtained, the years 2016 and 2017 had optimal conditions, whereas other years had drought conditions. Therefore, the growth of biochemical characteristics of the red currant plants in current study were tested and compared separately for optimal and drought seasons.

\section{Experimental studies and data collection}

In this study, three introduced cultivars ('Jonkheer van Tets', 'Hollandische Rote' and 'Viksne') and five Russian cultivars or genotypes ('Shchedraya', 'Natali', 129-2161, 111-19-81, 261-65-19 and 271-58-24) were tested. More information about the cultivars and genotypes is presented in Table 3. The site was planted in October 2010. A randomised complete block design (RCBD) with three blocks (replications) was used in the present study. A total of 40 registered plants were arranged in each replication according to the scheme with $0.5 \times$ $2.8 \mathrm{~m}$ dimensions. During data collection, 10 plants from each replication were used. The soil in the row spacing was kept under black steam during the research period. No irrigation was performed during the growing

Table 1. Some climatic characteristics of the experimental site.

\begin{tabular}{lllllll}
\hline Year & \multicolumn{2}{c}{$\begin{array}{c}\text { Average monthly } \\
\text { air temperature } \\
\left({ }^{\circ} \mathrm{C}\right)\end{array}$} & $\begin{array}{c}\text { Humidity } \\
(\mathrm{mm})\end{array}$ & \multicolumn{2}{c}{$\begin{array}{c}\text { Maximum soil } \\
\text { temperature } \\
\left({ }^{\circ} \mathrm{C}\right)\end{array}$} \\
\cline { 2 - 7 } & May & July & May & July & May & July \\
\hline 2014 & 16 & 19.1 & 37.1 & 20 & 46.6 & 53 \\
2015 & 19.5 & 20.8 & 44.2 & 79.1 & 56 & 46 \\
2016 & 17.7 & 21.2 & 47.2 & 66.5 & 34.5 & 31 \\
2017 & 16.3 & 22.2 & 56.3 & 85.5 & 38.5 & 41 \\
2018 & 17.7 & 21.2 & 31.4 & 120 & 42 & 29 \\
$\begin{array}{l}\text { Long- } \\
\text { term } \\
\text { average }\end{array}$ & 13 & 18.5 & 36.3 & 88.8 & N/A & N/A \\
\hline
\end{tabular}

Table 2. Hydrothermal coefficient of the experimental site during the study period.

\begin{tabular}{lccccc}
\hline Period & 2014 & 2015 & 2016 & 2017 & 2018 \\
\hline May & 0.27 & 0.81 & 1.21 & 1.11 & 0.62 \\
July & 0.34 & 0.98 & 1.05 & 1.25 & 0.94 \\
\hline
\end{tabular}

$\mathrm{K}>1.3$ represents excessive hydration; $\mathrm{K}=1.0-1.3$ represents optimal hydration; $K<1.0$ represents insufficient hydration

Table 3. Introduced and Russian red currant genotypes of the present study.

\begin{tabular}{lll}
\hline Genotype & & \multicolumn{2}{c}{ Origin } \\
\cline { 2 - 3 } Jonkheer van Tets & Genetic & Geographic \\
Natali & Faya Plodorodnaya $\times$ London Market & Russia \\
Hollandische Rote & Ribes vulgare $\times$ R. rubrum $\times$ Ribes petraeum & The Netherlands \\
Viksne & R. rubrum $\times$ Ribes petraeum & Latvia \\
Shchedraya & Ribes warscewiczii Jancz. & Russia \\
129-21-61 & Faya Plodorodnaya $\times$ Houghton Castle & Russia \\
$261-65-19$ & Jonkheer van Tets $\times$ Hollandische Rote & Russia \\
$111-19-81$ & Jonkheer van Tets $\times$ Ribes atropurpureum & Russia \\
$271-58-24$ & Jonkheer van Tets - free pollination & \\
\hline
\end{tabular}


period. Once a year (spring, early April) ammonium nitrate $\left(\mathrm{NH}_{4} \mathrm{NO}_{3}\right)$ was applied under the plants. After the occurrence of pests and diseases, chemical control was performed. Penconazole $\left(\mathrm{C}_{13} \mathrm{H}_{15} \mathrm{Cl}_{2} \mathrm{~N}_{3}\right)$ was used against Sphaerotheca mors-uvae, and malathion $\left(\mathrm{C}_{10} \mathrm{H}_{19} \mathrm{O}_{6} \mathrm{PS}_{2}\right)$ was applied against pests.

The selected forms (129-21-61, 111-19-81, 261-6519 and 271-58-24) were obtained by us in the Russian Research Institute of Fruit Crop Breeding (VNIISPK) currant breeding laboratory. These genotypes were obtained in 2007 by the method of combinative selection using intersort crosses of red currants of various genetic and geographical origins. For 3 years (2007-2010), field surveys were carried out on a set of economically valuable indicators (the degree of flowering, fruiting, weight accounting of the harvest, the state of plants after winter). Based on the results of the field assessment, four genotypes were selected for further laboratory studies. 'Jonkheer van Tets', 'Hollandische Rate' and 'Viksne' were obtained as cuttings from the Federal State Scientific Institution 'I. V. Michurin Federal Scientific Center' (Michurinsk, Russia). 'Natali' and 'Shchedraya' were also obtained as cuttings from the Federal Horticultural Centre for Breeding, Agrotechnology and Nursery Russian Federation.

During the growing seasons, observations were done on each genotype about the disease resistance/ sensitivity of the genotypes. The percent of disease scores (Table 4) were used for the observation of powdery mildew of red currants (Sphaerotheca morsuvae (Schw.) Berk et Curt.) and leaf spots (Pseudopeziza ribis Kleb). Ten bushes of each cultivar were examined during the observations.

\section{Berry yield and productivity indicators}

Harvesting of fruits had been performed from 1 to 10 July every year. Productivity was determined from three accounting plants of the same genotype in each replicate. The total yield of each genotype had been calculated and counted to present as tonne per hectare. The length of the raceme was measured from 10 accounting plants from each replication of each genotype. To determine the average weight of one berry, a sample of 100 berries from one genotype was weighed on a technical scale (Scout Pro SP202, Ohaus, USA) and divided by 100 . Berries were picked without choice.

\section{Biochemical compositions of the berries}

For biochemical analysis of berries, $300 \mathrm{~g}$ (from each genotype) of ripe berries was collected from 10 accounting plants of each replication. Samples (berries) for biochemical composition analysis were collected from 1 to 10 July in each season. The soluble solids concentration (SSS (sum sucrose soluble) - \% Brix) of the fruits was determined by using a digital refractomer PAL-3 (ATAGO, Tokyo, Japan). The content of the sum of sugars (sucrose + monosaccharide) was determined by the weight method according to Bertrand's method (Kumar et al., 2014). Titratable acidity (\%) was measured by titration with $0.1 \mathrm{M} \mathrm{NaOH}$ solution in the presence of a phenolphthalein indicator. Ascorbic acid content $\left(100 \mathrm{mg} \cdot \mathrm{g}^{-1}\right)$ was then determined by the iodometric method based on the titration of ascorbic acid in coloured extracts with potassium iodate $\left(\mathrm{KIO}_{3}\right)$ in an acidic medium in the presence of potassium iodide (KI) and starch. Finally, the total phenolic content $\left(100 \mathrm{mg} \cdot \mathrm{g}^{-1}\right)$, which was the total sum of contents of anthocyanins, leucoanthocyanins and catechins, was determined by a colourimetric method using a photocolorimeter photometer KFK3-'3OM3' (Zagorsk Optical and Mechanical Factories, Sergiev Posad, Moscow Region, Russia).

\section{Water regime of plants}

The studies were carried out in dynamics from 25 to 30 May and from 20 to 25 July. The intensity of transpiration was determined in the field by using a VT-500 torsion balance (Central Research Textile Institute, Russia) from 11:00 to 12:00. The first weighing measurement was carried out immediately after cutting the leaf (a), and the second one (b) was carried out after

Table 4. Disease scores followed for the observation of Sphaerotheca mors-uvae and Pseudopeziza ribis.

\begin{tabular}{|c|c|c|}
\hline Disease score & Sphaerotheca mors-uvae & Pseudopeziza ribis \\
\hline 0 & No infection (healthy plant) & No infection (healthy plant) \\
\hline 1.0 & $\begin{array}{l}\text { Very weak disease damage (up to } 10 \% \text { of leaves and up to } 1 \% \\
\text { of berries are affected) }\end{array}$ & $\begin{array}{l}\text { Very weak damage (up to } 5 \% \text { leaves } \\
\text { are affected) }\end{array}$ \\
\hline 2.0 & $\begin{array}{l}\text { Weak plant disease (up to } 1 / 4 \text { of the shrub shoots, up to } 25 \% \\
\text { of leaves and up to } 3 \% \text { of berries are affected) }\end{array}$ & $\begin{array}{l}\text { Weak plant damage (up to } 10 \% \text { of } \\
\text { the leaves are damaged) }\end{array}$ \\
\hline 3.0 & $\begin{array}{l}\text { Average plant disease (up to } 1 / 3 \text { of the shrub shoots, } 26-50 \% \text { of } \\
\text { the leaves and up to } 10 \% \text { of the berries are affected) }\end{array}$ & $\begin{array}{l}\text { Average plant damage (up to } 30 \% \text { of } \\
\text { leaves are damaged) }\end{array}$ \\
\hline 4.0 & $\begin{array}{l}\text { Severe plant disease ( }(1 / 3 \text { to } 1 / 4 \text { of the shrub shoots, } 51-70 \% \text { of the } \\
\text { leaves and up to } 20 \% \text { of the berries are affected })\end{array}$ & $\begin{array}{l}\text { Severe plant damage (up to } 50 \% \text { of } \\
\text { the leaves are damaged) }\end{array}$ \\
\hline 5.0 & $\begin{array}{l}\text { Very severe disease (more than } 1 / 2 \text { of the shrub shoots, more than } \\
70 \% \text { of the leaves and more than } 20 \% \text { of the berries are affected) }\end{array}$ & $\begin{array}{l}\text { Very severe damage (more than } 50 \% \\
\text { of the leaves are damaged) }\end{array}$ \\
\hline
\end{tabular}


2 min: this made it possible to measure the level of transpiration at the state of saturation of the leaf with water. To determine the level of transpiration, the leaf area was taken into account. The area of the leaf (S) was determined by die cutting using a cork drill with a diameter of $1.0 \mathrm{~cm}$; five die cuts were made from one leaf. The central vein and leaf plate were included in the sample. Then, the following formula was used to calculate the level of transpiration (I):

$$
I\left(\mathrm{mg} \cdot \mathrm{m}^{-2} \cdot \mathrm{h}^{-1}\right)=\frac{a-b}{t \times S}
$$

$I$ - transpiration rate

$\mathrm{a}$ - initial weight of the leaf (mg)

$\mathrm{b}$ - leaf weight in $2 \mathrm{~min}(\mathrm{mg})$

$\mathrm{t}$ - exposure time $(\mathrm{h})$

$\mathrm{S}$ - leaf area $\left(\mathrm{m}^{2}\right)$

The content of free and bound water in the leaves was determined according to the Okuntsova-Marinchik method (Voskresenskaya et al., 2008). The method is based on a change in the concentration of a sucrose solution when a leaf sample is immersed in it. Test tubes with stoppers were used. They were weighed; then, $2 \mathrm{ml}$ of $30 \%$ sucrose solution was poured and weighed again. Next, $2 \mathrm{~g}$ of crushed leaves was placed in a sucrose solution and weighed. After $2 \mathrm{~h}$, the refractive index of sucrose solution was determined in test tubes with plants using a PAL 1 refractomer (ATAGO, Tokyo, Japan). At the same time, the dry leaf mass (for bound water determination) of red currant cultivars was determined. Metal containers with a volume of $70 \mathrm{ml}$ were used. A leaf sample $(10 \mathrm{~g})$ was placed and dried in an artificial climate chamber 'Espec' PSL2KRN (ESPEC, Osaka, Japan) at $105^{\circ} \mathrm{C}$ for $3 \mathrm{~h}$. The containers were then placed in a desiccator with $\mathrm{CaCI}_{2}$ for cooling and then weighed. The total water content (\%) (WC.in.L) of the leaves was then calculated by taking the sum of free and bound water percentages. The coefficient of bound water (\%) / free water (\%) in leaves was calculated by taking into account the calculated ratio.

\section{Soil moisture determination}

Annual measurements were done for the determination of soil moisture and absolute soil moisture. The field soil moisture was estimated at a depth of 0-200 $\mathrm{mm}$ and 200-400 $\mathrm{mm}$ by drying the soil samples to a constant weight at a temperature of $105^{\circ} \mathrm{C}$ and then weighting on a Scout Pro SP202 technical scale (OHAUS, Parsippany, NJ, USA). Calculations were made according to the following formula (Mineev, 2001):

$W(\%)=\frac{a}{b} \times 100$

In the above formula, $\mathrm{W}$ is the soil moisture (\%), $\mathrm{a}$ is the mass of water evaporated during drying $(\mathrm{g})$ and $b$ is the mass of dry soil ( $g$ ). Then, the following formula was used for the calculation of the absolute soil moisture (W1):

$W 1(\%)=\frac{W}{F C} \times 100$

where $\mathrm{W}$ is the soil moisture (\%) and FC is the ultimate field moisture capacity. For FC, the field capacity (C) was multiplied with 0.43 , which was the value of the coefficient factor established experimentally for the loamy soil (Terpelets and Slyusarev, 2010):

$$
F C(\%)=C n 0.43
$$

\section{Statistical data processing}

The comparison of the studied genotypes was done according to the studied characteristics (disease resistance, biochemical composition, water regime, yield and etc.). The raw data of each parameter were subjected to analysis of variance (Draper and Smith, 2016) by using SPSS, version 22.0, and Excel software programmes. To characterise the indicators of the variation series, the mean value $(\mathrm{M})$, standard deviation $(\sigma)$ and significance level $(p<0.05)$ were used in combination. Correlations between variables were analysed using Pearson correlations. Principal component analysis (PCA) was then applied in order to reveal the relationships between the parameters and genotypes in the form of similarities and differences. The relationship of traits (water region of genotypes soil water conditions) was also evaluated by using the correlation analysis. Both the correlation analysis and PCA were performed with R 4.0.3. software (Free Software Foundation's GNU General Public License). The hierarchical clustering on principal components (HCPC) approach was then used to assess the degree of inter-genotype variability which allows users to combine the three standard methods of multivariate data analyses (Husson et al., 2010). PCA was used to reduce the dimension of the data into few continuous variables. The 'FactoMineR' and 'factoextra' packages in $\mathrm{R}$ 4.0.3. (Free Software Foundation's GNU General Public License) were used for HCPC analysis.

\section{RESULTS AND DISCUSSION}

\section{General findings and disease resistance}

The breeding programme at the institute is designed in such a way that the selection process is preceded by a genetic and statistical analysis of the studied quantitative traits. Therefore, the effectiveness of breeding experiments increases with a smaller volume of hybrid material. It is of great importance to determine the size of the selection of economically useful traits, which require a large cost to analyse. In the course of the work, combinations of crossing (interspecific hybridisation) of cultivars of European origin and species of red currants 
were carried out. The involvement in breeding practice of other species besides the cultivars of European origin reduced the quality index of berries. In the course of the study, several hybrid families were studied, including $>30$ seedlings, and such a number allowed us to analyse the inheritance of biochemical and economicbiological traits and to identify valuable genotypes (selected forms) for further study. In this experiment, the samples obtained on the basis of the descendant of the large - fruited Ribes vulgare subspecies - 'Jonkheer van Tets' were selected. In the conditions of a temperate continental climate, according to primary field observations, introduced cultivars and genotypes after dormant periods were characterised by minor damage due to negative winter temperatures.

Lesions of Aegeria tipuliformis $\mathrm{Cl}$. were found to be single cases and do not cause significant problems on the plants. The bushes had good annual growth (3-5 shoots per bush, height from $0.3 \mathrm{~m}$ to $1.2 \mathrm{~m}$ ). The flowering was harmonious $(70-80 \%$ of the flowers on the bushes). According to the field assessment of disease resistance, in years with optimal weather conditions, all the studied genotypes had higher infections of S. morsuvae damage than the drought season crops (Figure 1A). However, the damages of $P$. ribis showed a different occurrence while it became more problematic in drought conditions (Figure 1B). According to the results obtained, 'Hollandische Rote', 261-65-19 and 111-1981 had higher tolerance to $S$. mors-uvae than other genotypes. The most sensitive genotype was found to be 'Viksne', and the most sensitive season was found to be optimum conditions. Therefore, it was observed that the optimum conditions cause better growth of the plants and attraction of diseases. Many scientists who have studied the development of $S$. mors-uvae on berry crops (black currant, gooseberry and strawberry) explained this phenomenon by the age-related specialisation of the fungus which affects young shoots and leaves (Amsalem et al., 2006; Pluta et al., 2014; Saltykova et al., 2018). During the years of research, most of the studied cultivars and selected genotypes were affected by $P$. ribis to a medium (up to $10-15 \%$ ) or high degree (up to 30-40\%), and no resistant genotypes were found. The most least affected genotypes were observed to be 129-21-61, 111-19-81, 'Hollandische Rote' and 'Jonkheer van Tets'. These studies are confirmed by previously obtained results in Vilnius University Botanical Garden (Lithuania) on the resistance of red and black currants to leaf spots. Certain red currant cultivars ('Jonkheer van Tets', 'London Market', 'Hollandische Rote', 'Heinemanns Rote Spatlese' and 'Belaya Smoljaninovoj') are more resistant to spotting, and they also revealed a correlation between yield and spotting damage ( $r=0.79)$ (Zilinskaitë et al., 2003).

\section{Indicators of productivity}

Berry weight, yield, raceme length and the number of berries in a raceme are among the most important characteristics for the determination of productivity and economics of berry production. The data about these parameters are presented in Figure 2.

In terms of berry weight, a significant difference was observed among the test genotypes, where drought season only affected 'Jonkheer van Tets' and had no impact on other genotypes. Although there is no significant difference between the berry weights of optimum and drought seasons, the drought season fruits had slightly less berry weight than the optimum season fruits. The highest berry weight was noted in the 261-65-19 genotype (0.65 g), followed by the 129-21-61 genotype $(0.61 \mathrm{~g})$. The lowest berry weight was noted in 'Viksne' (0.36 g). Besides berry weight, the total yield is also a very important indicator of productivity. Contrary to the berry weight, the yield was found to be significantly affected by the drought season. Thus, the yield of each genotype was found to be significantly higher in optimum seasons than in drought seasons. Moreover, it was also noted that the berry weight alone is not a good indicator of productivity, where the 261-6519 genotype, which has the highest berry weight, was noted to have a moderate yield, and the highest yield was obtained in 'Hollandische Rote' $\left(15.6 \mathrm{t} \cdot \mathrm{ha}^{-1}\right)$. And the lowest yield was observed in the 111-19-81 genotype $\left(5.2 \mathrm{t} \cdot \mathrm{ha}^{-1}\right)$. The yield is also so related with the raceme length and number of berries in a raceme. Evaluation of such characteristics showed that the 271-58-24 genotype has the highest raceme length $(10.9 \mathrm{~cm})$, while 'Shchedraya' has the lowest raceme length $(5.3 \mathrm{~cm})$. Growing conditions were also noted to have a significant influence on the raceme length, and the highest raceme length was measured from plants growing under optimal conditions. Growing conditions had a similar impact on the number of berries in a raceme. Finally, the highest number of berries in a raceme was observed in the 271-58-24 genotype (13.6), and the lowest number was noted in 'Shchedraya' (7.2). A great economic value for farmers is not only the length of the raceme, the number of berries in a raceme, the weight of the berry and the yield, which are the components of productivity, but also the biochemical composition of the berries. The marketing policy in the sales markets is determined by the appearance of agricultural products, and in particular, for red currants, the length of the raceme, the number of berries in a raceme and berry weight are the appearance characteristics. Therefore, many breeding programmes for red currants are focussed on these characteristics. The biometric analyses made it possible to divide the studied genotypes into several groups according to the criteria developed by Knyazev and Bayanova (1999) (Table 5).

The genotype choice of agricultural plants corresponding to the region of cultivation, including for berry crops, is largely determined on the basis of the genotypic variability analysis of cultivars with respect to complex economically valuable characteristics. In terms of these characteristics, it is clear from the table that the most superior characteristics are obtained in the 271-58-24 genotype. Moreover, 'Jonkheer van Tets' and 
(A)

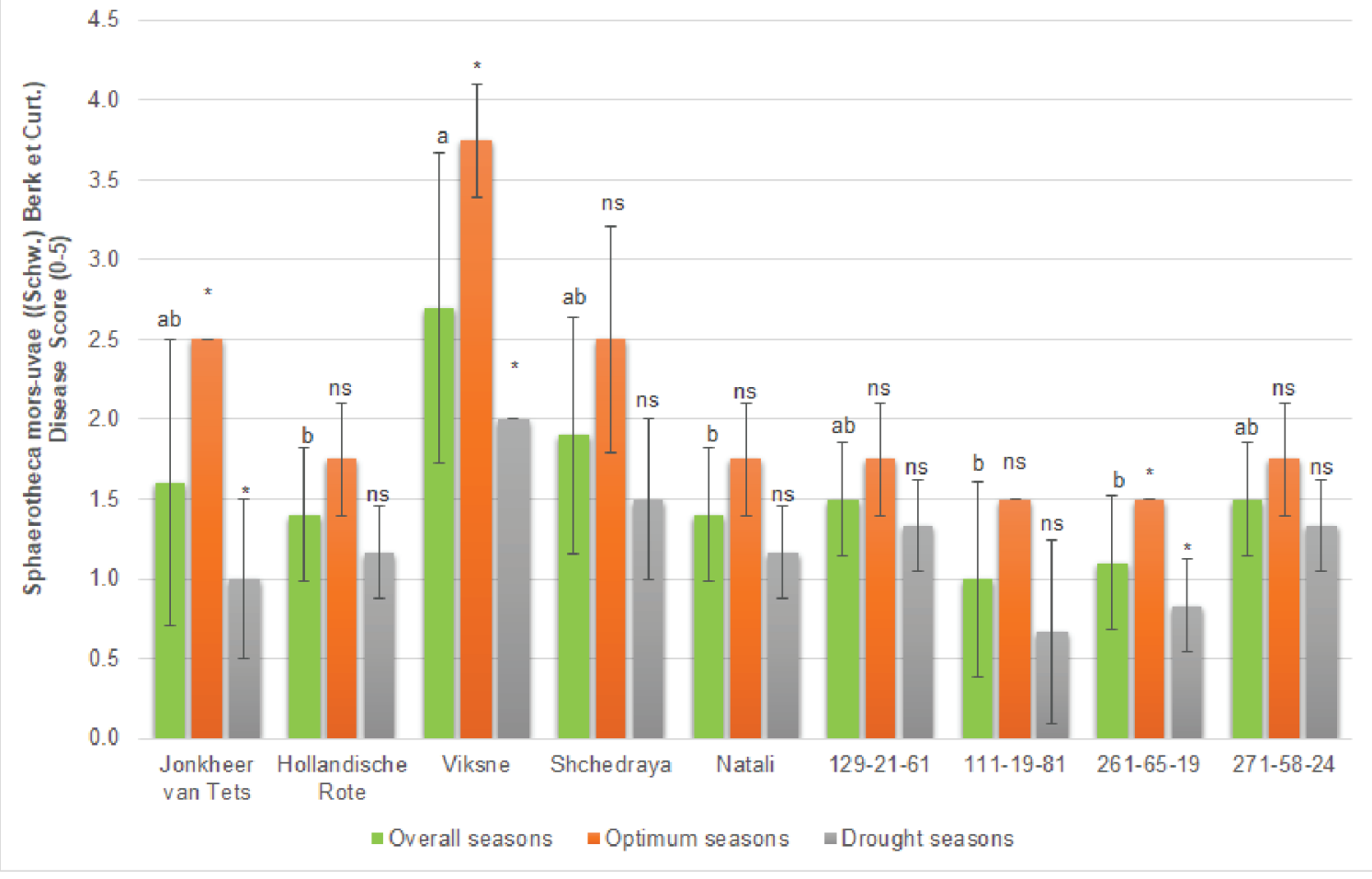

(B)

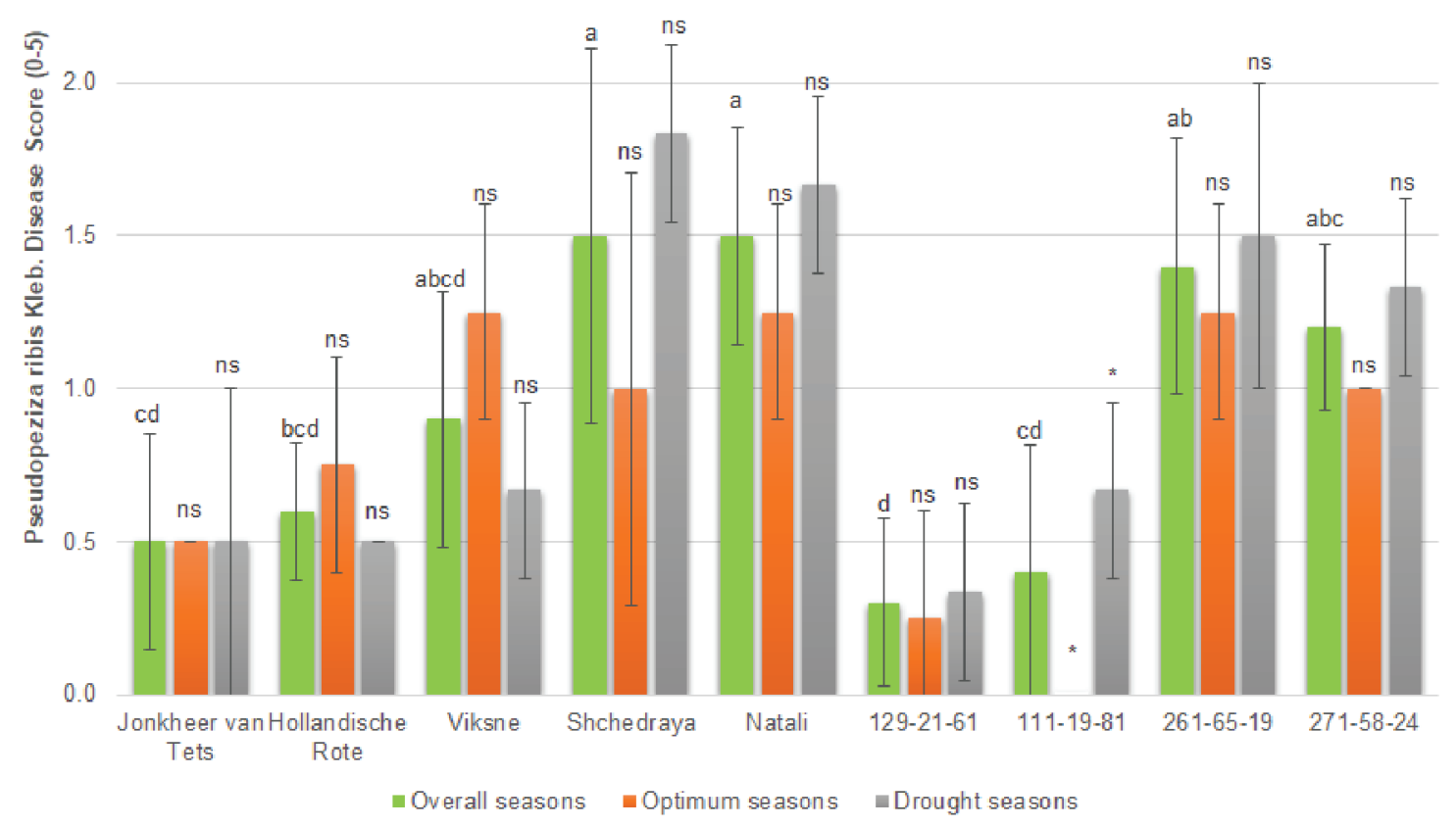

Figure 1. Disease scores of S. mors-uvae (A) and P. ribis (B) on the test genotypes in optimum and drought seasons. Averages of overall seasons that were compared for genotypes and different letters over the green columns were used to represent significant differences among the genotypes according to Tukey's test. Independent samples $t$-test was used to compare optimum and drought seasons separately for each genotype, ${ }^{*}$ Represents significant difference and ns means non-significant.

261-65-19 genotype have moderate biometric indicators for productivity.

\section{Biochemical composition of the genotypes}

In the course of the research, the biochemical composition (soluble solid concentration, titratable acidity and ascorbic acid and total phenolic contents) of the berries was also evaluated (Figure 3). Current results demonstrated that the climatic conditions have a significant influence on biochemical compositions. The SSC (soluble solid concentration) and TA (titratable acidity) were mostly found to be higher in optimal 
(A)

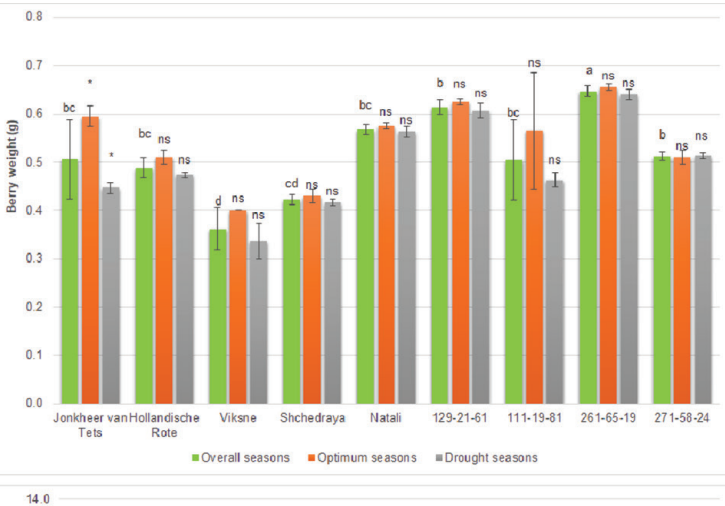

(C)

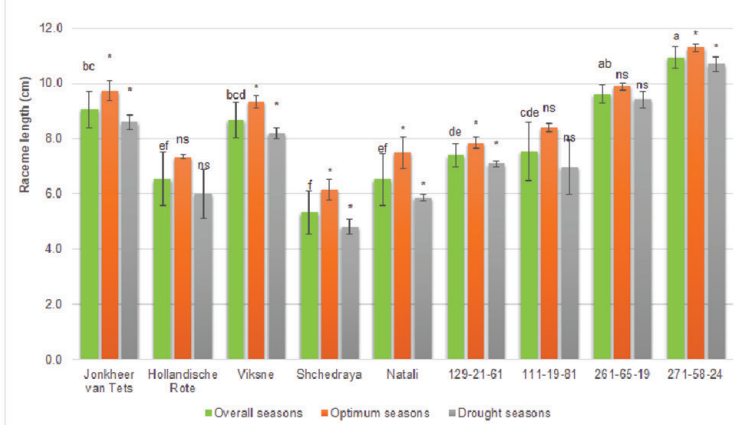

(B)

(D)
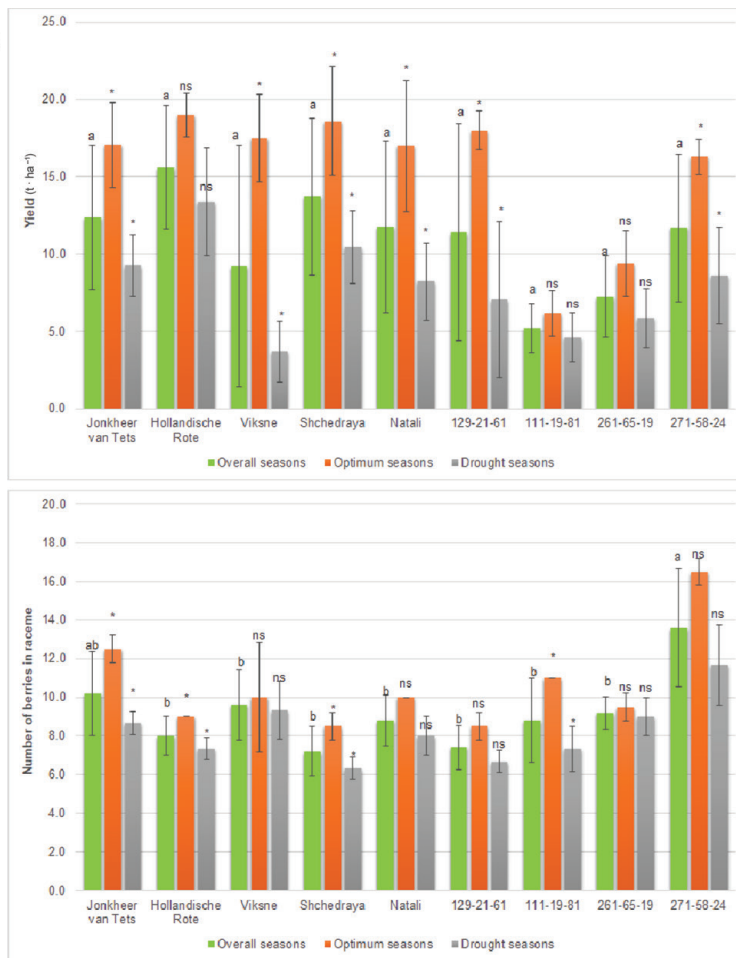

Figure 2. Berry weight (A), yield (B), raceme length (C) and the number of berries in a raceme (D) of test genotypes in optimum and drought seasons. Averages of overall seasons that were compared for genotypes and different letters over the green columns were used to represent significant differences among the genotypes according to Tukey's test. Independent samples t-test was used to compare optimum and drought seasons separately for each genotype, *Represents significant difference and ns means non-significant.

Table 5. Biometric indicators of productivity components.

\begin{tabular}{|c|c|c|c|c|c|c|c|c|c|}
\hline \multirow[t]{2}{*}{ Genotypes } & \multicolumn{3}{|c|}{$\begin{array}{c}\text { Raceme } \\
\text { length }\end{array}$} & \multicolumn{3}{|c|}{$\begin{array}{c}\text { Number of } \\
\text { berries in a } \\
\text { raceme }\end{array}$} & \multicolumn{3}{|c|}{$\begin{array}{c}\text { Berry } \\
\text { weight }\end{array}$} \\
\hline & 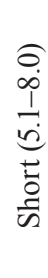 & 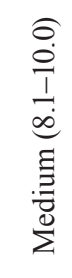 & 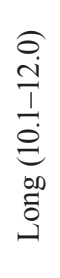 & 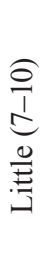 & 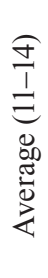 & 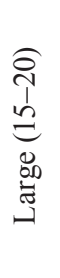 & 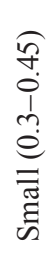 & 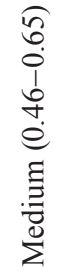 & 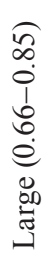 \\
\hline Jonkheer van Tets & & + & & & + & & & + & \\
\hline Natali & + & & & + & & & & + & \\
\hline Hollandische Rote & + & & & + & & & & + & \\
\hline Viksne & & + & & & + & & + & & \\
\hline Shchedraya & + & & & + & & & + & & \\
\hline $129-21-61$ & + & & & + & & & & + & \\
\hline $261-65-19$ & & + & & & + & & & + & \\
\hline $111-19-81$ & + & & & + & & & & + & \\
\hline $271-58-24$ & & & + & & & + & & + & \\
\hline
\end{tabular}

seasons, where the AA (ascorbic acid) and TPC (total phenolic contents) were mostly higher in drought seasons. A significant difference was noted among the cultivars/genotypes. The highest SSC content was noted in 'Hollandische Rote' and the lowest in 'Shchedraya'. On the other hand, the highest TA was observed in the 111-19-81 genotype and the lowest in 'Natali'. The high sugar content combined with the low organic acid content provides the berries with a pleasant sweet taste ('Natali', 'Viksne' and 'Hollandische Rote'). The balance of sugar to organic acids is important for describing the flavour characteristics of the fruits (Battino and Mezzetti, 2006; Talcott, 2007). Similar results were noted by Gorbunov and Kukushkina (2019) for some red currant genotypes which had a complex hybrid origin, i.e. as a result of crossing the species forms of red currants $R$. vulgare, $R$. rubrum and $R$. petraeum. Most of the other genotypes differed slightly in the studied trait. Belarusian and American scientists pointed out the absence of intercultivar differences in the accumulation of organic and phenolic compounds for berry crops (Rupasova et al., 1989; Dao et al., 2012; Berezina, 2019).

One of the important indicators of the nutritional value of berries is the content of ascorbic acid (Djordjević et al., 2010). The analysis of the obtained results (average for 2014-2018) showed a significant variability among the studied genotypes, which is consistent with the data obtained on this culture by other scientists (Talcott, 2007; Djordjević et al., 2010). The highest content of ascorbic acid was obtained in the selected form of 271-58-24, while 'Jonkheer van Tets', 'Hollandische Rote' and 'Natali' were characterised 
(A)

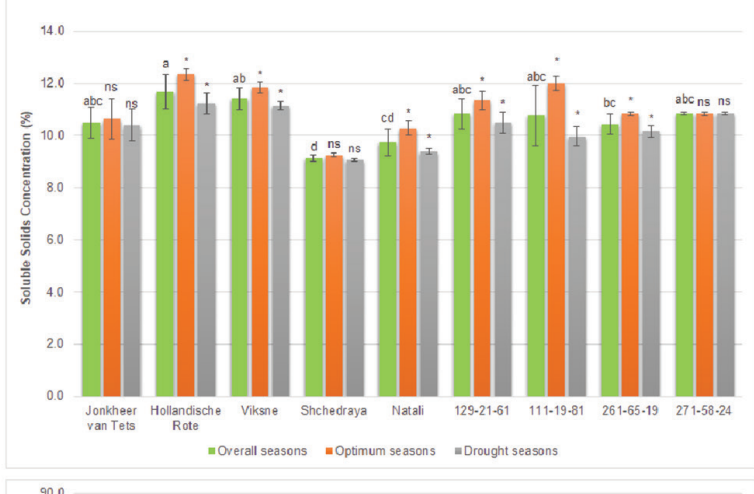

(C)

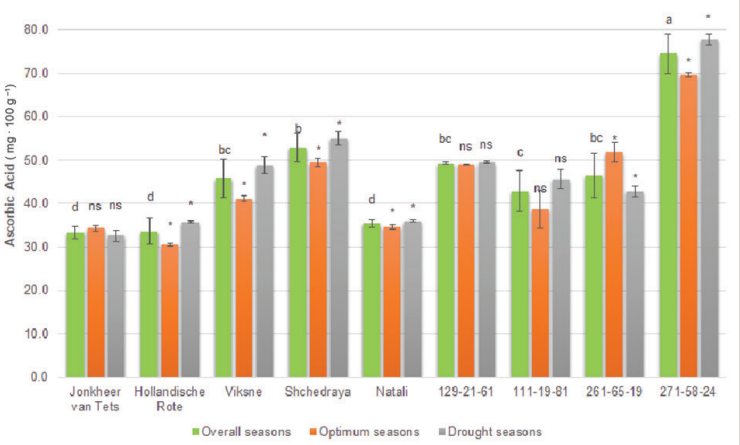

(B)

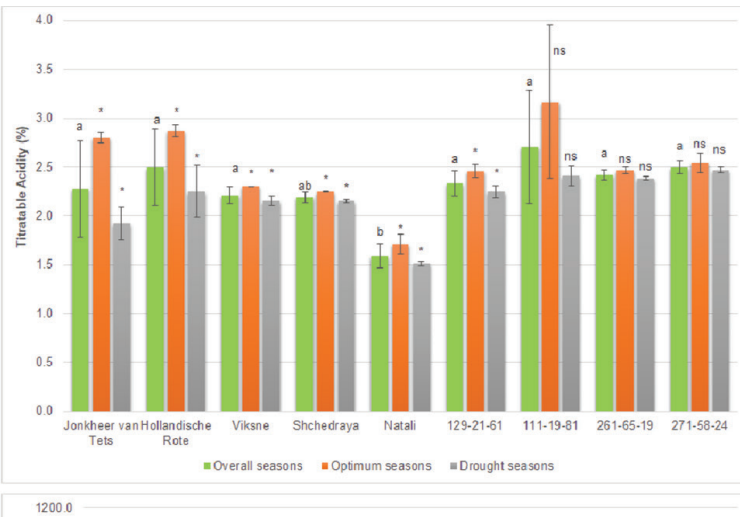

(D)

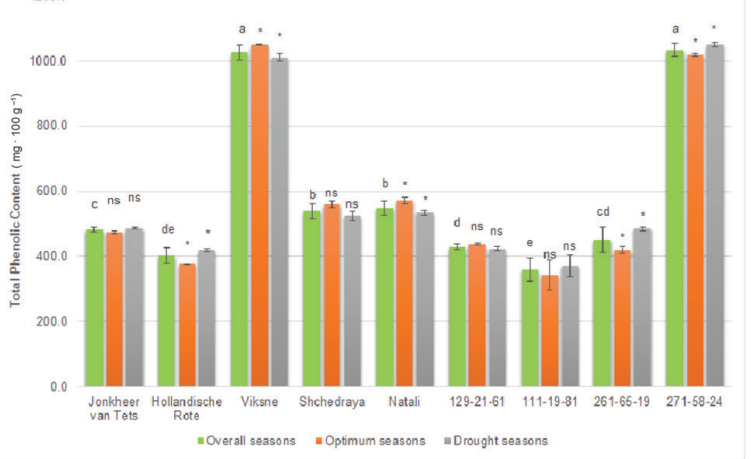

Figure 3. Soluble solid concentration (A), titratable acidity (B), ascorbic acid content (C) and total phenolic content (D) of test genotypes in optimum and drought seasons. Averages of overall seasons that were compared for genotypes and different letters over the green columns were used to represent significant differences among the genotypes according to Tukey's test. Independent samples t-test was used to compare optimum and drought seasons separately for each genotype, *Represents significant difference and ns means non-significant.

by a low index. Contrary to current results, in studies containing 'Jonkheer van Tets' grown in the regions of Belgium (Djordjević et al., 2010) and Turkey (Çelik and İslam, 2019), ascorbic acid content was found to be slightly higher but comparable with the data obtained in a temperate continental climate. Similar with the AA, the TPC of the fruits was found to be highest in the 271-58-24 genotype. No significant difference was noted between 'Viksne' and the 271-58-24 genotype. These two forms were observed to have about 2-fold of TPC than the others. The lowest content was noted in the 111-19-81 genotype.

\section{Clustering and genotype similarity}

A moderate positive correlation was found between the SSC and TA content of the berries (Figure 4A). A moderate negative correlation was observed between the SS and TA contents. A moderate-to-strong correlation was then observed between the AA and TPC of the berries, supporting the basic information that AA is a constituent of TPC of the fruits. One of the important results of the current study was about the correlation between the TPC and berry weight, which was moderately negative. Contrary, the TPC was found to have a moderately positive correlation with the raceme length and number of berries in a raceme. The highest correlation was observed between the raceme length and number of berries in a raceme. The impacts of the test traits on the cultivars/genotypes are shown in Figure 4B. Results demonstrated that 'Shchedraya' and 'Natali' are mostly characterised by their high yield, the 271-58-24 genotype by its high AA, TPC and the number of berries in a raceme, the 261-65-19 genotype, 'Viksne' and 'Jonkheer van Test' by the high raceme length, SSC, SS and TA and 'Hollandische Rote', 111-19-81 and 12921-61 genotypes by high berry weight. Hierarchical clustering (Figure 4C-4D) suggested four meaningful clusters: the introduced cultivars produced one cluster, Russian cultivars are another cluster, 261- 65-19, 111-1981 and 129-21-61 genotypes make up a third cluster and the 271-58-24 genotype (superior in terms of phenolic contents) forms the fourth cluster.

\section{Water regime and plant growth}

The yield and quality of products are determined by the state of the water regime of plants during the growing season. Throughout the studies, there were periods with optimal weather conditions and dry ones. An important indicator of the response of plants to stressful conditions (drought) is the assessment of water balance (El-Hendawy et al., 2019). A fairly accurate method of assessing the water status is focussed on traditional physiological measurements (Kovar et al., 2019). The water content in the leaves of the studied samples was determined in years with optimal moisture and in drought periods. At the same time, the field humidity of 


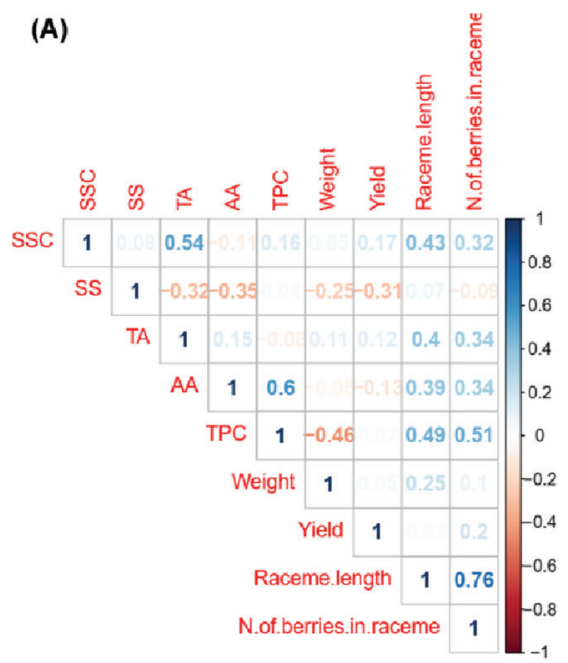

(C)

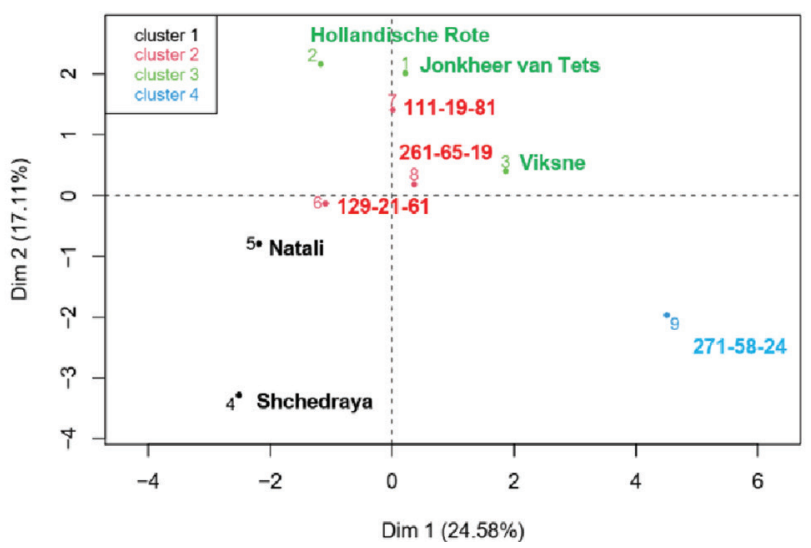

(B)

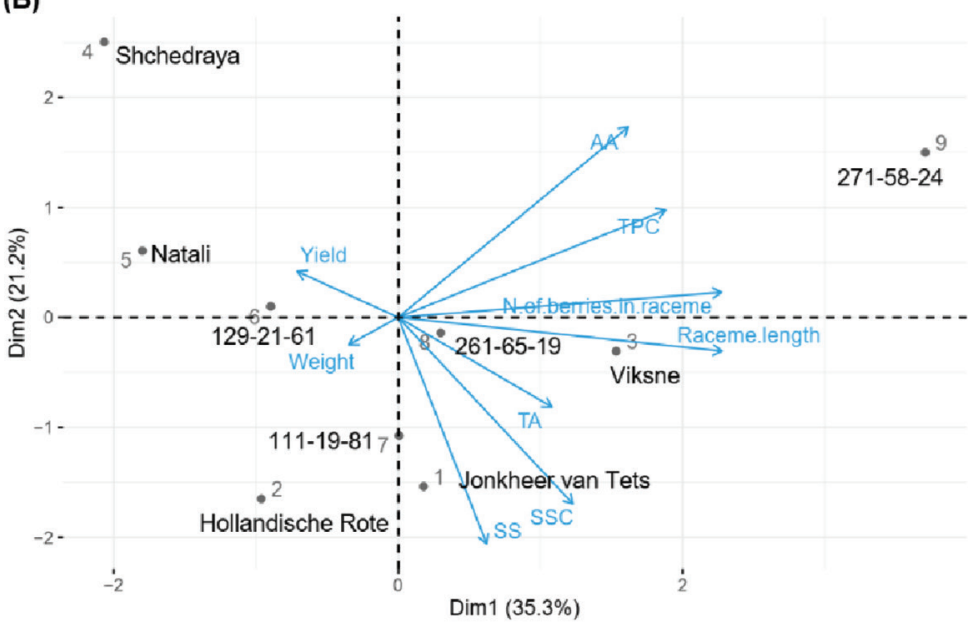

(D)

Hierarchical Clustering
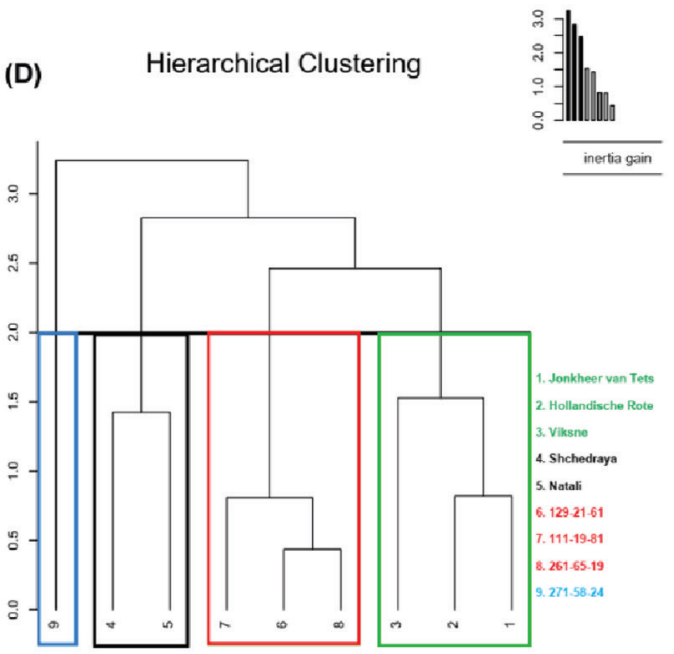

Figure 4. Correlation among selected traits (A), PCA - biplot with loadings (B), factor map (C) and hierarchical cluster (D) analysis of red currant genotypes.(1) 'Jonkheer van Tets'; (2) 'Hollandische Rote'; (3) 'Viksne'; (4) 'Shchedraya'; (5) 'Natali’; (6) 129-21-61; (7) 111-19-81; (8) 261-65-19 and (9) 271-58-24. PCA, principal component analysis.

the soil at a depth of $0-200 \mathrm{~mm}$ and $200-400 \mathrm{~mm}$ was taken into account. The correlation among the traits is described in Figure 5. Results suggested that there is a very strong negative correlation between bound water and free water of leaves in May, and this correlation decreases in July. At the same time, a strong positive correlation was observed between the coefficient of bound/free water and bound water. The bound water in leaves was negatively correlated with the soil moisture and absolute soil moisture in the top layer (0-200 mm). This correlation decreased in July and was found to be negligible in lower layers $(200-400 \mathrm{~mm})$. Contrary to bound water, free water had a positive correlation with the soil moisture content of the soil. Simply, it can be concluded that the increase in the soil moisture content in the upper layers can cause an increase in the free water content of the leaves and a decrease in the bound water content of the leaves. Moreover, these correlations were higher in May as compared with those in July. It was also found that the water content of leaves and transpiration have a strong positive relationship with soil moisture at a depth of 0-200 $\mathrm{mm}$ but a week correlation with soil moisture at a depth of 200-400 mm. Results also showed that the transpiration of the leaves decreases in later developmental stages.

According to the results obtained, the optimal soil moisture content for the growth and development of plants is considered to be at least $70 \%$. In the conditions of the field experiment, this corresponds to $17.3 \%$ of the absolute soil moisture (Roeva and Motyleva, 2013). At the same time, the moisture reserve in the underlying soil layers $(200-400 \mathrm{~mm})$ is higher than that in the upper horizon. Similar results were obtained by other scientists. It is suggested that fruit plants get the necessary amount of moisture due to the growth of roots in the deeper layers of the soil. The biomass of roots located in the deep layers of the soil correlates with the content of moisture reserve in the underlying layers of the soil ( $r=0.88)$ (Wang et al., 2012).

The supply of moisture to plants is determined not only by the water content in the soil but also by the ability of plants to absorb it. The quantitative moisture content in the assimilation apparatus of red currant genotypes, as well as the change in this indicator during 


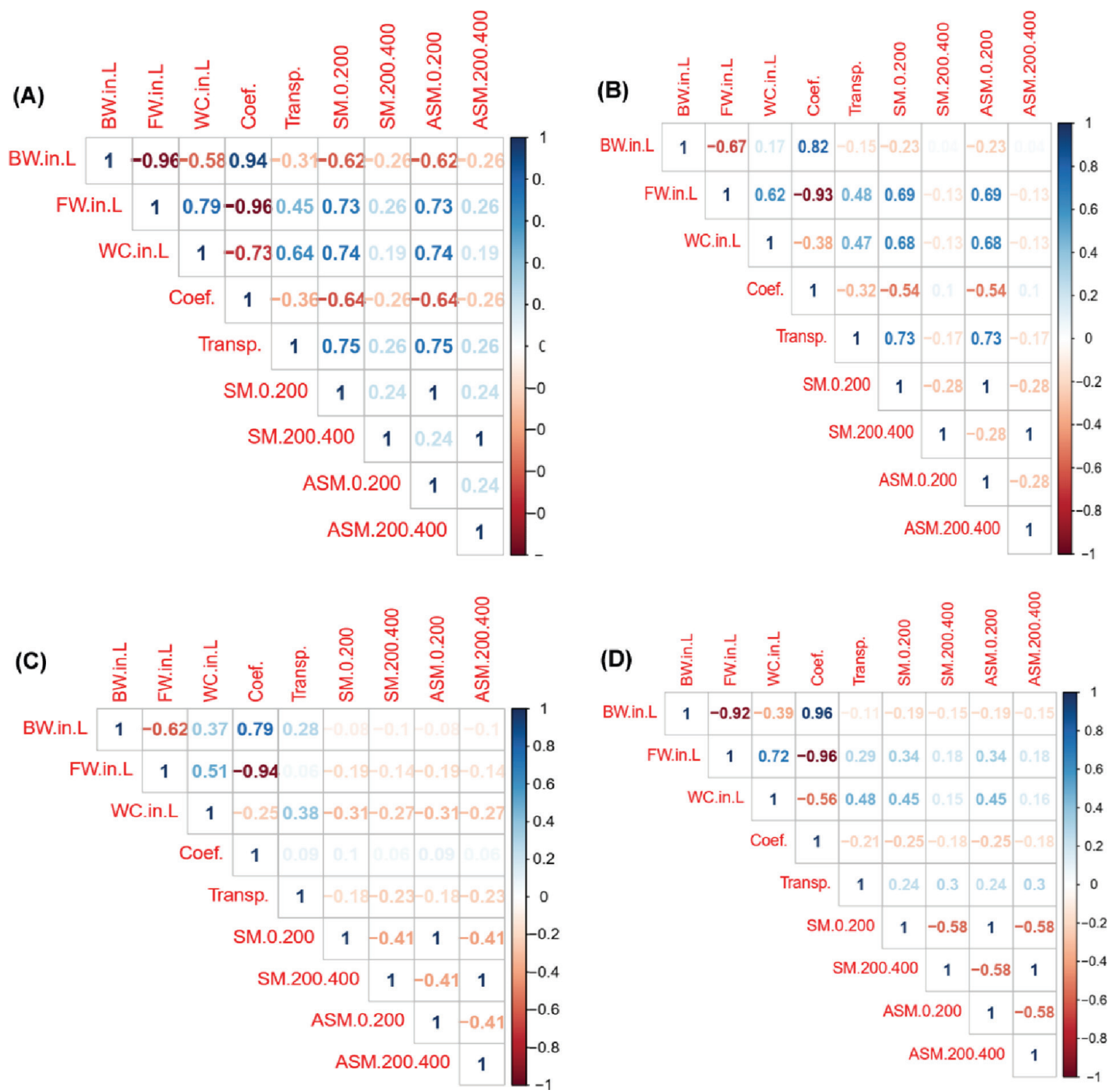

Figure 5. Correlation among selected water regime traits in soil and plant leaves of red currant plants in May (A), July (B), drought season (C) and optimum season (D). ASM.0-200, absolute soil moisture (\%) at 0-200 mm; ASM.200400, absolute soil moisture (\%) at 200-400 mm; BW.in.L, bound water in leaves (\%); Coef., coefficient of bound/free water (\%); FW.in.L, free water in leaves (\%); SM.0-200, soil moisture (\%) in 0-200 mm; SM.200-400, soil moisture $(\%)$ in 200-400 $\mathrm{mm}$; Transp., transpiration $\left(\mathrm{mg} \cdot \mathrm{m}^{-2} \cdot \mathrm{h}^{-1}\right)$; WC.in.L, water content (\%).

the growing season and growing conditions, allow us to give an objective assessment of water balance of plants and assess the degree of drought resistance. The water content in the leaves reflects the complex effect of air and soil drought. In the course of the research, direct linear dependence of the level of soil horizon moisture and leaf hydration was revealed. Under optimal weather conditions, the water content in the leaves was high (on average $64.68 \%$ ), and the plants absorb the required amount of moisture from the soil horizon at a depth of 0-200 $\mathrm{mm}$. In drought season, the water content in the leaves decreased (to an average of $60.59 \%$ ), and the plants used water for growth and development from lower layers with a thickness of $200-400 \mathrm{~mm}$. The maximum reduction in leaf hydration was in 'Shchedraya' and in the 261-65-19 selected form.

By the time of berry maturation (July) and due to the physiological ageing of the leaf blade, the water content in the leaves of red currants decreases (Figure 6), and this phenomenon does not depend on environmental conditions (Keller et al., 2006). The studies have shown the variability of this trait during the growing season in conditions of optimal moisture. The highest values of bound water to free water were in 'Hollandische Rote', 'Jonkheer van Tets' and the 271-58-24 selected form. From May to July, there is an increase in bound water content and, at the same time, a sharp decrease in the rate of water loss. There is a decrease in the overall 
(A)

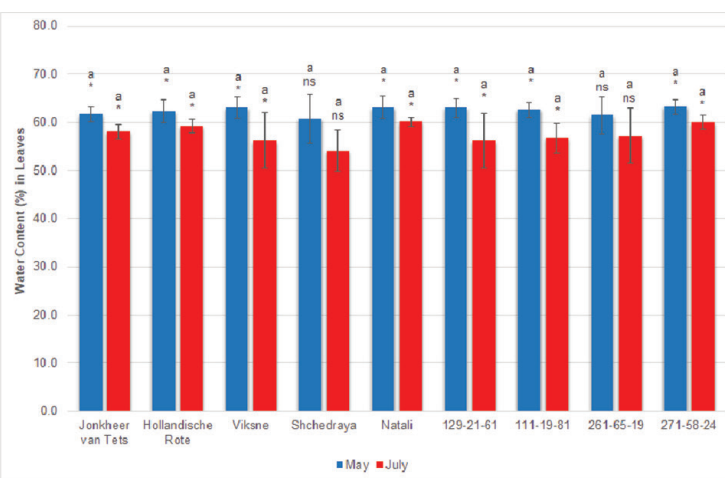

(B)

(C)
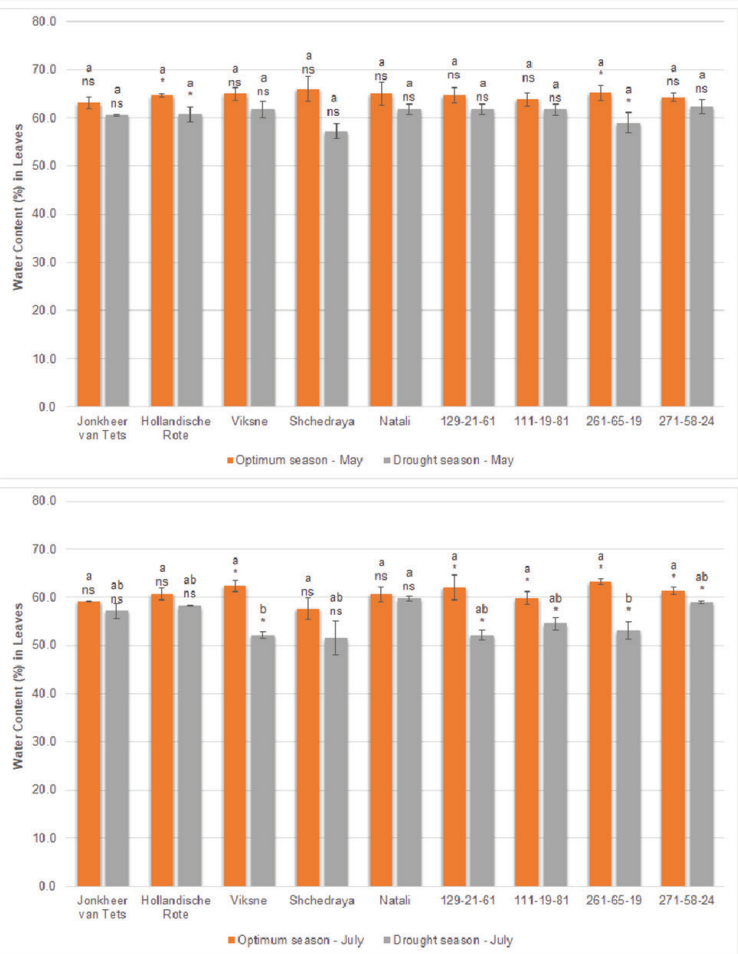

(D)

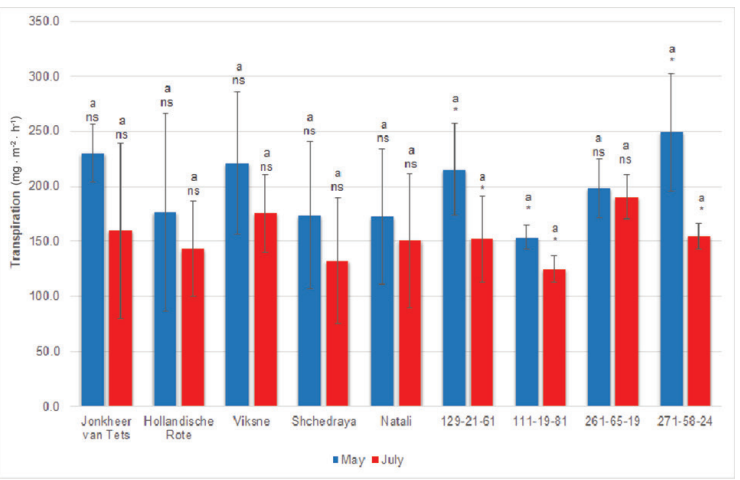

(E)

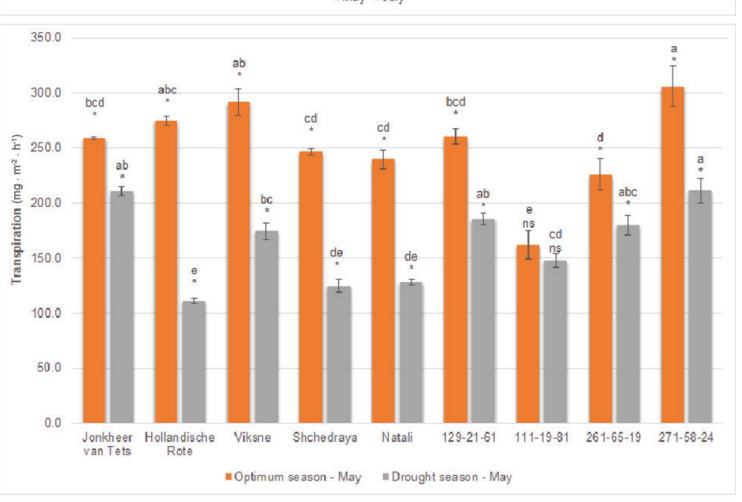

(F)

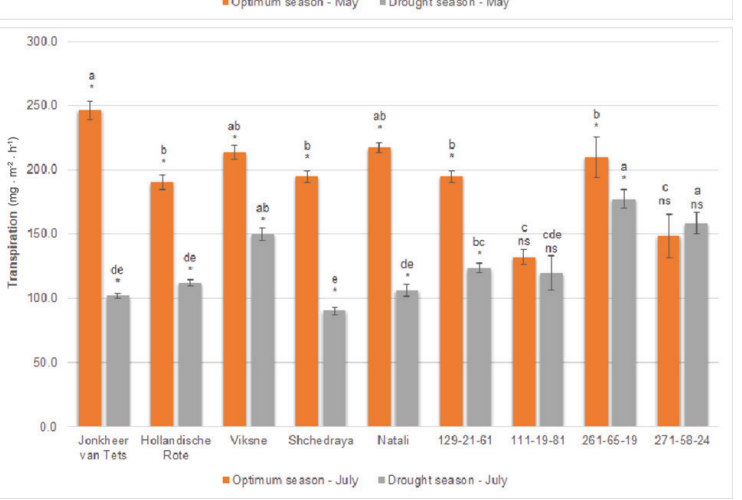

Figure 6. Comparison of the water content of leaves in May and July (A), optimum and drought seasons in May (B) and optimum and drought seasons in July (C); and comparison of transpiration of genotypes in May and July (D), optimum and drought seasons in May (E) and optimum and drought seasons in July (F). Averages of overall seasons that were compared for genotypes and different letters over the columns were used to represent significant differences among the genotypes according to Tukey's test. Independent samples t-test was used to compare May and July or optimum and drought seasons separately for each genotype, *Represents significant difference and ns means non-significant.

water content of the leaves since water loss depends on the water content of the leaves. According to the literature data, as this content decreases, the amount of water that can be evaporated from the leaf surface progressively decreases (Williams and Amer, 1957). In addition, the increase in temperature and average humidity in July compared to May is the reason for a decrease in the rate of water loss since high humidity interferes with the normal course of the transpiration process and negatively affects the movement of nutrients and water through the xylem and the regulation of temperature and the movement of the closing cells of plant stomata (Kuznetsov and Dmitrieva, 2005). The intensity of transpiration during this period decreased sharply in comparison with optimal conditions, which was associated with a decrease in the rate of nutrient and water supply to photosynthetic cells and the movement of the closing stomatal cells. In more drought-resistant forms of plants, the evaporation process was less intense than in unstable ones (Morales et al., 2013; Basu et al., 2016). The study revealed a positive correlation between the level of transpiration and soil moisture and a negative relationship between transpiration and the amount of bound water in the plant.

The results of the water regime indicators are considered as one of the important elements in the regulation of the production process and help assess the ability of the studied red currant genotypes to tolerate the stress factors of the growing season with minimal yield losses. However, 'Hollandische Rote', 'Jonkheer 
van Tets', 'Shchedraya' and the 271-58-24 selected form showed high yields consistently $\left(9.5-20.0 \mathrm{t} \cdot \mathrm{ha}^{-1}\right)$. According to the field observations, these genotypes were characterised by a lower percentage of berry shedding. For farms, the establishment of plantations with these cultivars would allow us to get a fairly high profit and ensure the profitability of crop production in a temperate continental climate. For scientific institutions, these genotypes are of interest to attract breeding for adaptability and yield.

\section{CONCLUSIONS}

This study was aimed at assessing and understanding the adaptation process of introduced cultivars and breeding genotypes of red currants in temperate continental climates and regions with a similar climate. Based on the long-term study of the red currant cultivar phenotypes, it has been found that the choice of a particular cultivar for production or breeding research is determined by genotypic variability based on the analysis of economically valuable and adaptively significant traits. None of the selected genotypes was found to be resistant to any of the diseases/pests, but 'Jonkheer van Tets', 'Hollandische Rote' and 111-1981 were less affected from these diseases/pests. The highest berry weight was observed in the 261-65-19 genotype $(0.65 \mathrm{~g})$, while the highest yield was noted in 'Hollandische Rote' $\left(15.6 \mathrm{t} \cdot \mathrm{ha}^{-1}\right)$.

In periods of unstable hydrothermal conditions, the cultivars of foreign selection have developed and maintained a system of morphological and physiological adaptations that protect them from stress factors. These studies clearly show the dependence of the yield of the cultivar upon the state of the water regime of plants and soil moisture. The direct dependence of the water content of the leaves of the introduced red currant cultivars on the soil moisture and the soil horizon has been revealed. The nature of the correlation relationships made it possible to determine the direction of individual trait selection. The degree of drought resistance of cultivars is determined by the amount of bound water in the leaves, the rate of transpiration and the period of development. Accurate information about the period of plant ontogenesis when plants experience the greatest moisture deficiency can be taken into account in breeding programmes to increase the resistance of cultivars to drought. Indicators of the water regime of red currant cultivars can be used to predict the yield. The cultivars of European and Russian breeding such as 'Hollandische Rote', 'Jonkheer van Tets' and 'Shchedraya' retain their resistance to the stress factors of the growing season of the temperate continental climate. In the framework of breeding programmes aimed at finding sources and donors of valuable economic-biological and adaptive significant traits, it is necessary to use selected forms obtained on the basis of the descendant of a large-fruited subspecies Ribes rubrum - 'Jonkheer van Tets'.

\section{FUNDING}

This work was supported by the Russian Ministry of Education and Science (Research No. 0467-2022-0001).

\section{AUTHOR CONTRIBUTIONS}

O.P. contributed in investigation, methodology and writing, preparing and editing the draft. M.T. contributed with software, editing and conceptualisation. V.O. helped in the preparation and editing of the original draft. S.K. contributed with data curation and methodology. O.G. contributed in visualization and investigation. I.K. contributed with data curation, writing the review and editing.

\section{CONFLICT OF INTEREST}

Authors declares no conflict of interest.

\section{REFERENCES}

Albuguerque, T. G., Silva, M. A., Oliveira, M. B. P. P., And Costa, H. S. (2018). Analysis, identification, and quantification of anthocyanins in fruit juices. In G. Rajauria and B. Tiwari (Eds), Fruit juices extraction, composition, quality and analysis (pp. 693-737). New York, USA: Academic Press.

Álvarez-Herrera, J., González, H., and Fischer, G. (2019). Water potential in cape gooseberry (Physalis peruviana L.) plants subjected to different irrigation treatments and doses of calcium. Agronomía Colombiana, 37(3), 274-282.

Amsalem, L., Freeman, S., Rav-David, D., Nitzani, Y., Sztejnberg, A., Pertot, I., and Elad, Y. (2006). Effect of climatic factors on powdery mildew caused by Sphaerotheca macularis f. sp. fragariae on strawberry. European Journal of Plant Pathology, 114(3), 283-292.

Basu, S., Ramegowda, V., Kumar, A., and Pereira, A. (2016). Plant adaptation to drought stress. F1000Research, 5, 1554, doi: 10.12688/f1000research. 7678.1

Battino, M., And Mezzetti, B. (2006). Update on fruit antioxidant capacity: A key tool for Mediterranean diet. Public Health Nutrition, 9(8A), 1099-1103.

BerezinA, E. V. (2019). Accumulation of phenolic compounds in lingonberries (Vaccinium vitis-idaea L.) and cranberries (Oxycoccus palustris Pers. O. Macrocarpus (Ait.) Pers.) in vivo, in vitro and ex vitro. $\mathrm{PhD}$ dissertation, Moscow State University, Russia, pp. 160.

Bratsch, T., AND Tech, V. (2009). Off-season management tasks and considerations for selected small fruit crops. Virginia Cooperative Extension (VCE), 1-3.

Bratsch, T., and Williams, J. (2009). Specialty crop profile: Ribes (currants and gooseberries). Virginia Cooperative Extension (VCE), 1-14. 
Ceccarelli, S., and Grando, S. (2020). Evolutionary plant breeding as a response to the complexity of climate change. Science, 23(12), 101815, doi: 10.1016/j.isci.2020.101815.

Çelik, E., And İslam, A. (2019). Investigations on some properties of currant and gooseberry varieties grown in organic condition. International Journal of Agriculture Forestry and Life Science, 3(1), 64-74.

Čereković, N., Pagter, M., Kristensen, H. L., Pedersen, H. L., Brennan, R., and Petersen, K. K. (2013). Effects of drought stress during flowering of two pot-grown blackcurrant (Ribes nigrum L.) cultivars. Scientia Horticulturae, 162, 365-373.

Chartzoulakis, K., Patakas, A., Kofidis, G., Bosabalidis, A., And Nastou, A. (2002). Water stress affects leaf anatomy, gas exchange, water relations and growth of two avocado cultivars. Scientia Horticulturae, 95(1-2), 39-50.

Chirkov, Yu. I. (1986). Agrometeorology. Leningrad, Russia: Hydrometeoizdat.

Cosmulescu, S., Baciu, A., and Gruia, M. (2008). Physiological changes in black currant cultivars under suboptimal culture conditions. Bulletin UASVM, Horticulture, 65(1), 318-322.

Dao, C. A., Patel, K. D., and Neto, C. C. (2012). Phytochemicals from the fruit and foliage of cranberry (Vaccinium macrocarpon)-potential benefits for human health. In B. S. Patil, G. K. Jayaprakasha, K. N. C. Murthy, and N. P. Seeram (Eds), Emerging trends in dietary components for preventing and combating disease (pp. 79-94). Washington, USA, American Chemical Society.

Duordjević, B., Šavikin, K., Zdunić, G., Janković, T., Vulić, T., Oparnica, Č., and Radivojević, D. (2010). Biochemical properties of red currant varieties in relation to storage. Plant Foods for Human Nutrition, 65(4), 326-332.

Draper, N., and Smith, H. (2016). Applied regression analysis. New York, USA: John Wiley \& Sons.

El-Hendawy, S. E., Al-Suhaibani, N. A., Elsayed, S., Hassan, W. M., Dewir, Y. H., Refay, Y., And Abdella, K. A. (2019). Potential of the existing and novel spectral reflectance indices for estimating the leaf water status and grain yield of spring wheat exposed to different irrigation rates. Agricultural Water Management, 217, 356-373.

Gilbert, J., And Gardner, L. (2003). Commercial potential and development of new berry crops: an overview. Acta Horticulturae, 626, 369-373.

Golyaeva, O. D., Panfilova, O. V., and Kalinina, O. V. (2020). Plant breeding evaluation of the red currant cultivar 'Podarok Pobeditelyam' and its inbred progeny. Proceedings on Applied Botany, Genetics and Breeding, 181(2), 35-41.

Gorbunov, A. B., and Kunushrina, T. A. (2019). The chemical composition of berries of species and interspecific hybrids of red currant in the conditions of culture. Chemistry of Vegetable Raw Materials, 3, 85-93.
Grabowski, J., Kawecki, Z., BienieK, A., AND TomaszewsKa, Z. (2009). Weather conditions during the blossoming period and their effect on the yield of three cultivars of blackcurrant (Ribes nigrum L.). Folia Horticulturae, 21(2), 35-42.

Guerfel, M., Baccouri, O., Boujnah, D., Chaївi, W., AND ZARROUK, M. (2009). Impacts of water stress on gas exchange, water relations, chlorophyll content and leaf structure in the two main Tunisian olive (Olea europaea L.) cultivars. Scientia Horticulturae, 119(3), 257-263.

Gündeşli, M. A., Korkmaz, N., and Okatan, V. (2019). Polyphenol content and antioxidant capacity of berries: A review. International Journal of Agriculture Forestry and Life Sciences, 3(2), 350-361.

Heeb, L., Jenner, E., And Cock, M. J. (2019). Climatesmart pest management: building resilience of farms and landscapes to changing pest threats. Journal of Pest Science, 92(3), 951-969.

Hummer, K. E., And Dale, A. D. A. M. (2010). Horticulture of ribes. Forest Pathology, 40(3-4), 251-263.

Husson, F., Josse, J., And Pages, J. (2010). Principal component methods-hierarchical clusteringpartitional clustering: why would we need to choose for visualizing data. Technical Report of the Applied Mathematics Department (Agrocampus), 1-17.

Jimenez-Garcia, S. N., VazQuez-Cruz, M. A., GarciaMier, L., Contreras-Medina, L. M., GuevaraGonzález, R. G., Garcia-Trejo, J. F., And Feregrino-Perez, A. A. (2018). Phytochemical and pharmacological properties of secondary metabolites in berries. In A. M. Holban and A. M. Grumezescu (Eds), Therapeutic foods (pp. 397-427). New York, USA: Academic Press.

Kapoor, D., Bhardwaj, S., Landi, M., Sharma, A., Ramakrishnan, M., and Sharma, A. (2020). The impact of drought in plant metabolism: how to exploit tolerance mechanisms to increase crop production. Applied Sciences, 10(16), 5692.

Kawecki, Z., Bieniek, A., Kopytowski, J., AND Siksnianas, T. (2006). Preliminary assessment of productivity and fruit quality of Lithuanian and Ukrainian cultivars of blackcurrant under the climatic conditions of Olsztyn. Journal of Fruit and Ornamental Plant Research, 14, 75-80.

Keller, M., Smith, J. P., And Bondada, B. R. (2006). Ripening grape berries remain hydraulically connected to the shoot. Journal of Experimental Botany, 57(11), 2577-2587.

Klamkowski, K., and Treder, W. (2008). Response to drought stress of three strawberry cultivars grown under greenhouse conditions. Journal of Fruit and Ornamental Plant Research, 16, 179-188.

Knyazev, S. D., and Bayanova, L. V. (1999). Currants, gooseberries and their hybrids. In E. N. Sedov (Ed.), Program and methods of variety investigation of fruit, berry and nut crops (pp. 351-374). Orel, Russia: Vniispk. 
Kovar, M., Brestic, M., Sytar, O., Barek, V., Hauptvogel, P., and Zivcak, M. (2019). Evaluation of hyperspectral reflectance parameters to assess the leaf water content in soybean. Water, 11(3), 443.

Kumar, C. C., Mythily, R., Venkatachalapathy, R., And Chandraju, S. (2014). Bio-mimic conversion of Maida (polysaccharides) to reducing sugars by acid hydrolysis and its estimation using standard methods. International Food Research Journal, 21(2), 523.

Kumar, R., Berwal, M. K., and Saroj, P. L. (2019). Morphological, physiological, biochemical and molecular facet of drought stress in horticultural crops. International Journal of Bio-resource and Stress Management, 10(5), 545-560.

Kusmec, A., Zheng, Z., Archontoulis, S., Ganapathysubramanian, B., Hu, G., Wang, L., Yu, C., AND Schnable, P. S. (2021). Interdisciplinary strategies to enable data-driven plant breeding in a changing climate. One Earth, 4(3), 372-383.

Kuznetsov, V. V., and Dmitrieva, G. A. (2005). Plant physiology. Moscow, Russia: High School.

Łakomiak, A., And Zhichkin, K. A. (2020). Economic aspects of fruit production: A case study in Poland. BIO Web of Conferences, 17, 00236, doi: 10.1051/ bioconf/20201700236.

MilošEvić, T., AND MilošEvić, N. (2018). Vegetative growth, productivity, berry quality attributes and leaf macronutrients content of currants as affected by species and cultivars. Erwerbs-Obstbau, 60(1), 53-65.

Mineev, V. G., Sychev, V. G., and Amelianchik, O. A. (2001). Workshop on agrochemistry. Moscow: MSU.

Morales, C. G., Pino, M. T., And Del Pozo, A. (2013). Phenological and physiological responses to drought stress and subsequent rehydration cycles in two raspberry cultivars. Scientia Horticulturae, 162, 234-241.

Myhre, G., Alterskjer, K., Stjern, C. W., Hodnebrog, Ø., Marelle, L., Samset, B. H., And Stohl, A. (2019). Frequency of extreme precipitation increases extensively with event rareness under global warming. Scientific Reports, 9(1), 16063, doi: 10.1038/s41598-019-52277-4.

Netzer, Y., Munitz, S., Shtein, I., and Schwartz, A. (2019). Structural memory in grapevines: Early season water availability affects late season drought stress severity. European Journal of Agronomy, 105, 96-103.

OKATAN, V. (2020). Antioxidant properties and phenolic profile of the most widely appreciated cultivated berry species: A comparative study. Folia Horticulturae, 32(1), 79-85.

Olen, B., Wu, J., And Langpap, C. (2016). Irrigation decisions for major west coast crops: Water scarcity and climatic determinants. American Journal of Agricultural Economics, 98(1), 254-275.

Panfilova, O., Knyazev, S., Golyaeva, O., Tsoy, M., and Kalinina, O. (2021). Features of adaptation of varieties and selected forms of different types of red currants to damaging abiotic factors. Bulgarian Journal of Agricultural Science, 27(1), 80-87.

Pedersen, H. (2007). Black and red currants cultivars for low pesticide production. Paper presented at the NJF $23^{\text {rd }}$ Congress 2007, Trends and Perspectives in Agriculture, Copenhagen, Denmark, 188-189.

Pedersen, H., And Andersen, L. (2012). Black and red currant cultivars for organic production. Paper presented at the $15^{\text {th }}$ International Conference on Organic Fruit Growing, Hohenheim, Germany, 215-220.

Pereira, C. C., Da-Silva, E. N., De-Souza, A. O., Vieira, M. A., Ribeiro, A. S., and Cadore, S. (2018). Evaluation of the bioaccessibility of minerals from blackberries, raspberries, blueberries and strawberries. Journal of Food Composition and Analysis, 68, 73-78.

Pluta, S., Żurawicz, E., Studnicki, M., And Mądry, W. (2014). Combining ability analysis for selected plant traits in gooseberry. Journal of the American Society for Horticultural Science, 139(3), 325-335.

Rodyukova, O. S. (2008). Study of the adaptive and productive potentials of currants as a source material for selection and improvement of assortment. $\mathrm{PhD}$ dissertation, Michurinsk State Agrarian University, Russia, pp. 22.

Roeva, T. A., And Motyleva, S. M. (2013). Effect of zeolite containing rocks and weather conditions on heavy metal income in black currant berries. Contemporary Horticulture, 1, 1-12.

Rupasova, Z. A., Ignatenko, V. A., Rusalenko, V. G., and Rudakovskaya, R. N. (1989). Razvitie i metabolizm klyukvy krupnoplodnoi v Belorusskom Poles'e [The development of large-fruited cranberry and metabolism in Belarusian Polesie]. Science and Technology, Minsk, BY.

Saltykova, T. I., Vakhrusheva, N. S., and Sofronov, A. P. (2018). Study of weather influence on mildew affection of black currant in Kirov region. Contemporary Horticulture, 2, 634.723.1:632 (In Russian).

TAlcott, S. T. (2007). Chemical components of berry fruits. In Y. Zhao (Ed.), Fruit. Value-added products for health promotion (pp. 51-73). Boca Raton, FL, USA: Taylor and Francis Group.

Tereshchenko, YA.Yu. (2018). Selection of industrial assortment of red and white currants for the Western Forest-steppe of Ukraine. $\mathrm{PhD}$ dissertation, Institute of Horticulture of NAAS, Kyiv, pp. 216.

Terpelets, V. I., AND Slyusarev, V. N. (2010) Teaching-methodological guide for the study of agrophysical and agrochemical methods of studying soils. Krasnodar, Russia: Kuban State Agrarian University.

Voskresenskaya, O. L., Grosheva, N. P., and Skochilova, E. A. (2008). Plant physiology. Yoshkar-Ola: Mariinsky State University, Russia.

Wang, Y., ShaO, M. A., Liu, Z., And Warrington, D. N. (2012). Regional spatial pattern of deep soil water 
content and its influencing factors. Hydrological Sciences Journal, 57(2), 265-281.

Wiethold, J. (2016). Red currant and black current, new cultivated fruits in late medieval and early modern Europe: Historic and archaeobotanical evidence. In M.-P. Ruas (Ed.), Des fruits d'ici et d'ailleurs. Regards sur l'histoire de quelques fruits consommés en Europe (pp. 267-284). Paris, France: Omniscience.

Williams, W. T., And Amer, F. A. (1957). Transpiration from wilting leaves. Journal of Experimental Botany, 8(1), 1-19.

Zavala, J. A., Casteel, C. L., Delucia, E. H., and Berenbaum, M. R. (2008). Anthropogenic increase in carbon dioxide compromises plant defense against invasive insects. Proceedings of the National Academy of Sciences, 105(13), 5129-5133.
Zdunić, G., ŠAvikin, K., Pluevluakušić, D., AND Duordjević, B. (2016). Black (Ribes nigrum L.) and red currant (Ribes rubrum L.) cultivars. In M. Simmonds and V. Preedy (Eds), Nutritional composition of fruit cultivars (pp. 101-126). London, United Kingdom: Academic Press.

Zilinskaitë, S., Meidus, E., And Meiduvienë, A. (2003). Genetic resources of the genus Ribes in VilniusUniversity Botanical Garden: I. Resistance ofcurrant and gooseberry cultivars to mildew (Sphaerotheca mors-uvae Berk. et Curt.) and leafspot (Pseudopeziza ribis Kleb.) and fruitage in 1998-2001. Biologija, 1, 14-17.

Received: June 24, 2021; accepted: July 24, 2021 